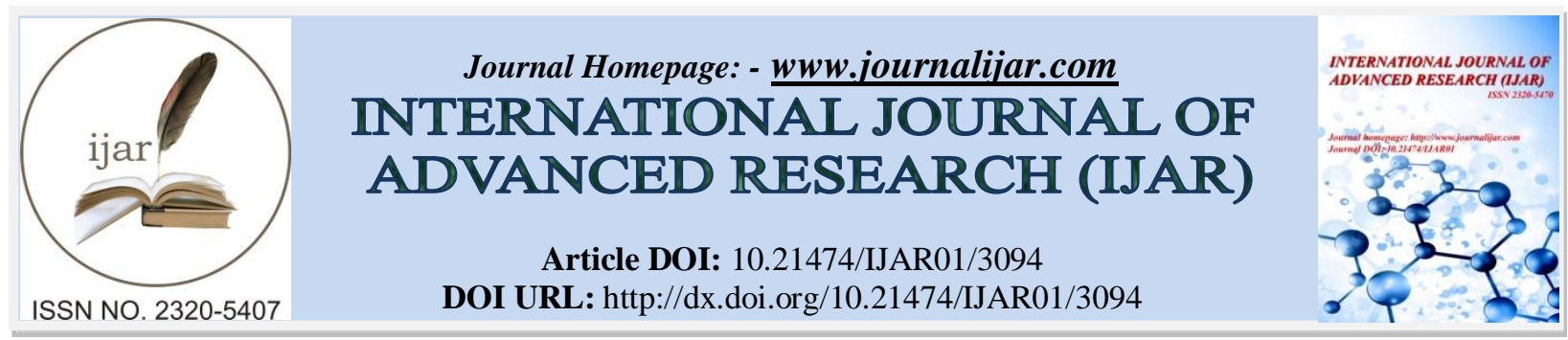

RESEARCH ARTICLE

\title{
SPECIES DIVERSITY AND DISTRIBUTION OF MOLLUSCAN FAUNA FROM ESTUARY AND MANGROVES (CORINGA WILDLIFE SANCTUARY) OF EAST GODAVARI ESTUARINE ECOSYSTEM, ANDHRA PRADESH, INDIA.
}

\section{Jarugulla Eswar Satyanarayana $^{{ }^{*}}$ and P.V. Krishna ${ }^{2}$.}

1. Department of Environmental Sciences, Acharya Nagarjuna University, Nagarjuna Nagar -522510, Guntur, Andhra Pradesh, India.

2. Department of Zoology \& Aquaculture, Acharya Nagarjuna University, Nagarjuna Nagar - 522510, Guntur, Andhra Pradesh, India.

\section{Manuscript Info}

Manuscript History

Received: 03 November 2016

Final Accepted: 28 December 2016

Published: January 2017

Key words:-

Mangrove, estuarine, Species richness, abundance, Coringa.

\section{Abstract}

Study on the diversity of molluscan fauna was carried out in different locations in the mangrove areas and estuary region of the East Godavari estuary ecosystem. This study determined the abundance and diversity of molluscs in the East Godavari estuarine ecosystem. A total of 14 Gastropods and 8 bivalves were reported from the mangrove areas and estuary region were documented. Onchidium $\mathrm{Sp}$. which is considered to be the shell-less terrestrial gastropod mollusc was also recorded from this mangrove area.

Copy Right, IJAR, 2016,. All rights reserved.

\section{Introduction:-}

Phylum Mollusca with more than 100000 recognized species (Feldkamp, 2002) play an important role in ecosystem function for forage of predators in their habitats. The term molluscs refer to an ecological group of invertebrates that belong to many lesser known creatures (Mardiastuti, 2001).

The term molluscs are relatively know compared to other components of the mangrove habitats (Kober, 2004; Mardiastuti,2001; Smith \& Nol, 2000). The Gastropoda with an estimated 75000 to 150000 species are the most diverse class of molluscs in the marine habitats (Strong et al. 2008) such as mangroves (Vermeij, 1973) and terrestrial habitats (Barker, 2001). It has been shown that gastropod assemblages massively contribute to feeding resources of waders within the mangrove ecosystem (Al-Sayed et al., 2008). Although classically the role of mangrove gastropods in nutrient dynamics has been largely overlooked, studies have demonstrated their central ecological role (Fratini et al. 2008).

Mangroves are intertidal vegetation along tropical and subtropical shorelines (Zhang et al. 2007), which have special physiological adaptations to frequently inundate by the tides (Lewis Iii, 2005). These unique ecosystems provide a large number of biological, ecological, economic, scientific, environmental, aesthetic and ethical values (Mitsch, 2005) including controlling tide level (Varnell et al. 2003) reducing effects of wave and wind energy against shorelines (Miththapala, 2008), stabilizing shorelines (Lee \& Shih, 2004). Thus mangroves protect inland structures (Lewis Iii, 2005), support coastal fisheries (Walters et al., 2008), provide diverse habitat to support wildlife communities including a large number of waterbirds, especially waders (Lewis Iii, 2005), and so many other direct and indirect benefits (Gustavson et al. 2009; Zhou et al. 2010).

Corresponding Author:- Jarugulla Eswar Satyanarayana.

Address:- Department of Environmental Sciences, Acharya Nagarjuna University, Nagarjuna Nagar 522510, Guntur, Andhra Pradesh, India. 
Molluscs support economically in the fishery sector and the ambiance of our coastal communities are frequently overlooked with diversity of these marine organisms. Molluscan populations as a source of food, ornamental purposes and commercial uses have brought under the shade of endangered species Shanmugam and Vairamani (2005).

Marine invertebrates are considered an important link between the initial detritus at the bases of the food web and the terminal consumers (Coull et al . 1995). The information regarding the role of invertebrates in the mangrove ecosystem are quite scanty, however, molluscs and crustaceans are important components of the ecosystem (Jiang and Li, 1995; Wells,1983, 1990; Milward, 1982; Redfield, 1982).

In the Phylum, Mollusc, about 3270 species have been reported from India belonging to 220 families and 591 genera. Among them the Bivalves are the most diverse (1100 species) followed by Gastropods (190 species). In India, about 215 species of mollusc were reported from mangrove areas of east and west coasts (Boominathan et al. 2012). In Andhra Pradesh a total of 120 molluscs have been reported. In the present study 22 molluscs species were recorded. East Godavari estuary ecosystem of east coast of India is an estuarine mangrove complex and supports a wide variety of biological species.

\section{Materials and Methods:-}

\section{Study area:-}

Coringa Wildlife Sanctuary is located between $16^{\circ} 44^{\prime}$ to $16^{\circ} 53^{\prime} \mathrm{N}$ and $082^{\circ} 14^{\prime}$ to $082^{\circ} 22^{\prime} \mathrm{E}$ and at the confluence of the river Godavari with the Bay of Bengal in the East Godavari District of Andhra Pradesh. The sanctuary is a part of the Godavari Estuary and has extensive mangrove cover. The total area is 235.7 sq. $\mathrm{km}$. The average temperature of the region is $17^{\circ} \mathrm{C}$ to $40^{\circ} \mathrm{C}$. Average Rainfall is greater than $1,000 \mathrm{~mm}$. The Northern part of sanctuary is covered by the back waters of the Kakinada Bay and covers an area of about $100 \mathrm{sq} . \mathrm{km}$.

Due to seasonal distribution of rainfall, East Godavari estuary ecosystem experiences seasonal flooding which introduces a lot of detritus and pollutants from the land.

The estuary region presently serves as a major drainage channel receiving domestic wastes as well as industrial effluents from the industrial area of Kakinada.

Visits to the sampling sites were made during 2015 to 2016. Four sites were thoroughly visited for molluscan diversity and their distribution pattern. Two sampling points were taken from the estuary region and two sites were taken from the mangrove area. Each sampling site was recorded using a Garmin etrex 10 GPS receiver. Photographs were taken at the sampling area and some of the samples were collected and were preserved in $70 \%$ alcohol for identification in the field station.

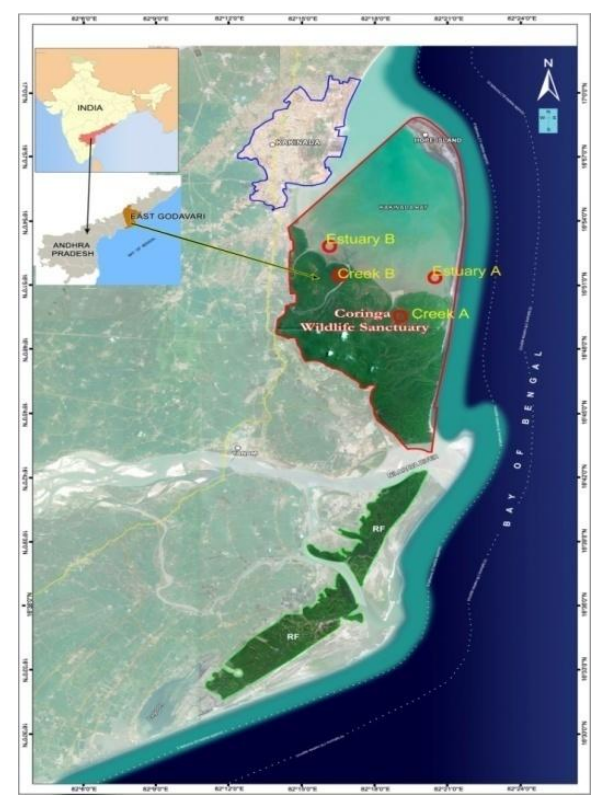




\section{Results and Discussions:-}

The aim of the study was to assess the molluscan faunal biodiversity in the mangroves and estuary regions of East Godavari estuary ecosystem. During the study period 14 Gastropods and 8 bivalves from the mangrove areas and estuary region were documented (Table- 1). Onchidium Sp. which is considered to be the shell-less terrestrial gastropod mollusc was also recorded from this mangrove area.

In the present study, the recorded specimens were found to occur on mud banks, mud flats, mangrove forest, sandy muddy area swamps and hard substratum. Gastropods and bivalves are generally benthos organisms, they consider to be used as bio indicators of aquatic healthy. Gastropods and bivalves can produce a billion of larvae in the form of planktons that sustains the biotic population and they have a role in food chain. The observation of Gastropods and bivalves populations in mangrove ecosystem is important to evaluate their condition Dewiyanti and Karina(2012).

Clithon oualaniense, Murex trapa, Pirenella cingulata, Placuna placenta, Nassarius dorsatus and Fusinus colus are found in the estuary region, Crassostrea bilineata were densely found on the trunks, pneumatophores and stilt rots of mangrove plants are found at the adjacent mangrove areas.

Table 1:- List of Molluscan species observed during the study period.

\begin{tabular}{|c|c|c|}
\hline S.No & Species & Authority \\
\hline & Gastropods & \\
\hline 1 & Assiminea brevicula & (Pfeiffer, 1855) \\
\hline 2 & Cassidula nucleus & (Gmelin, 1791) \\
\hline 3 & Cerithidea obtusa & (Lamarck, 1822) \\
\hline 4 & Littoraria melanostoma & (Gray, 1839) \\
\hline 5 & Neripteron violaceum & (Gmelin, 1791) \\
\hline 6 & Pythia plicata & (Ferussac, 1821) \\
\hline 7 & Telescopium telescopium & (Linnaeus, 1758) \\
\hline \multirow[t]{2}{*}{8} & Terebralia palustris & (Linnaeus, 1767) \\
\hline & Bivalves & \\
\hline 9 & Crassostrea bilineata & (Roding, 1798) \\
\hline 10 & Brachidontes exustus & (Linnaeus, 1758) \\
\hline 11 & Perna viridis & (Linnaeus, 1758) \\
\hline 12 & Teredo navalis & Linnaeus, 1758 \\
\hline 13 & Tegillarca granosa & (Linnaeus, 1758) \\
\hline 14 & Tegillarca rhombea & (Born, 1778) \\
\hline \multirow[t]{2}{*}{15} & Meretrix meretrix & (Linnaeus, 1758) \\
\hline & Estuarine & \\
\hline 16 & Clithon oualaniense & (Lesson, 1831) \\
\hline 17 & Murex trapa & Roding, 1798 \\
\hline 18 & Pirenella cingulata & (Gmelin, 1791) \\
\hline 19 & Placuna placenta & (Linnaeus, 1758) \\
\hline 20 & Nassarius dorsatus & (Röding, 1798) \\
\hline 21 & Fusinus colus & ( Linnaeus ,1758) \\
\hline 22 & Onchidium Sp. (Slug) & \\
\hline
\end{tabular}

Narasimham (1973) Radhakrishna and Ganapati (1967) observed that Anadara granosa and Placuna placenta were restricted in distribution along the western and southern side of the bay. Similar observations were made in the estuarine region of the Coringa Wildlife Sanctuary where the Placuna placenta and Anadara granosa were harvested by the shell collectors from the estuary region. Rajendar kumar (2016) has reported 10 gastropods and 5 species of bivalves recorded in the Coringa mangroves. Present study reported the molluscan fauna from both mangrove areas and estuarine regions.

Telescopium telescopium were found in the two sites of the mangrove areas which were abundant along the fish bone canals which were dug for facilitating water to the regeneration of the mangrove plantation by the forest department. 
Cassidula nucleus, Pythia plicata and Cerithidea obtuse has been observed to be on the same trunk of a tree during the high tide.

Molluscan fauna (Gastropods) recorded during the study in the Mangrove areas and estuarine regions in East Godavari estuarine ecosystem

\section{Gastropods}

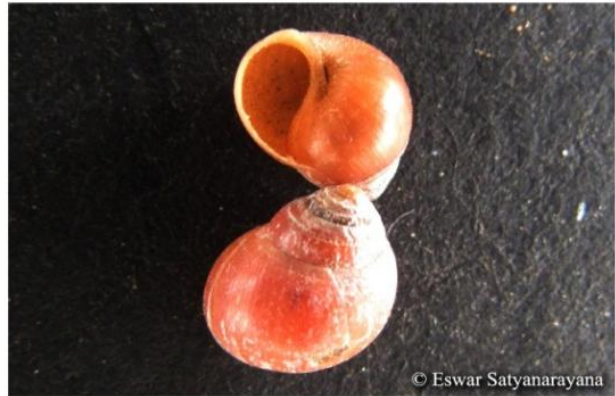

Assiminea brevicula (Pfeiffer, 1855)

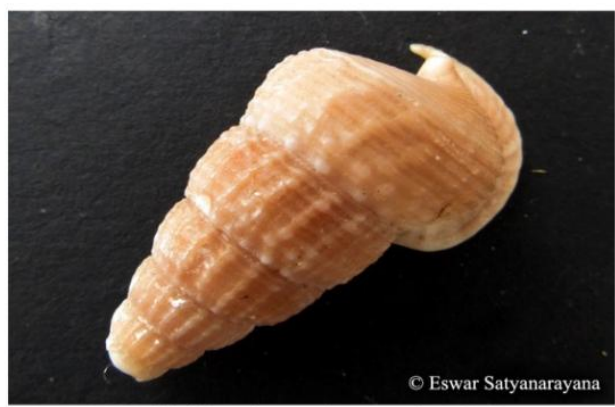

Cerithidea obtusa (Lamarck, 1822)

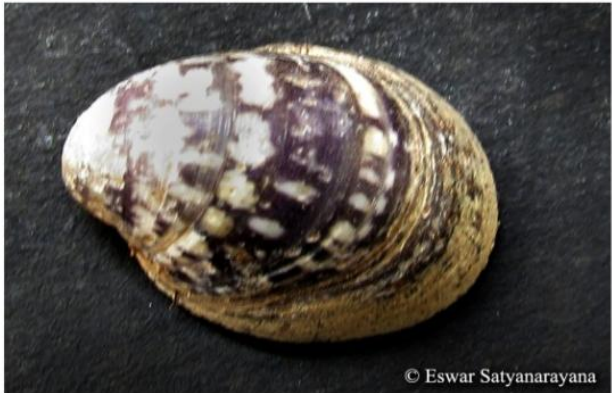

Neripteron violaceum (Gmelin, 1791)

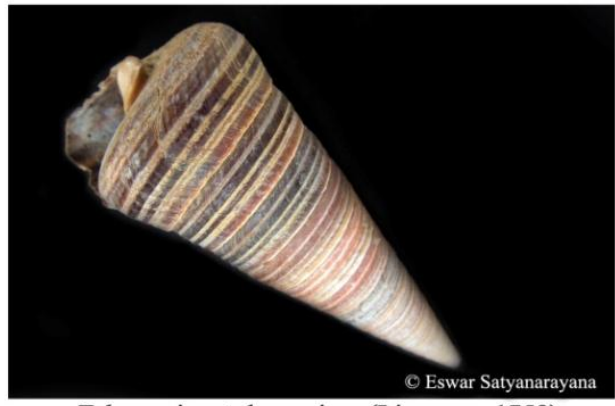

Telescopium telescopium (Linnaeus, 1758)

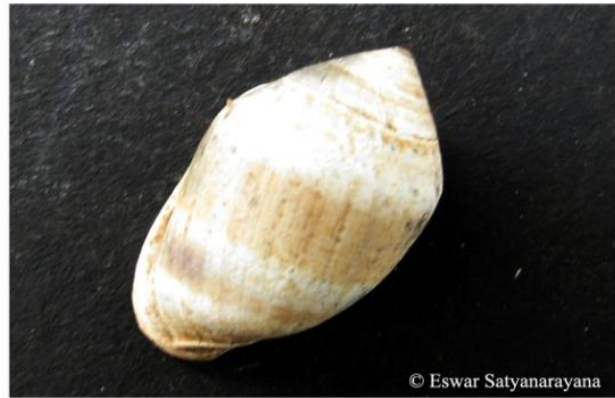

Cassidula nucleus (Gmelin, 1791)

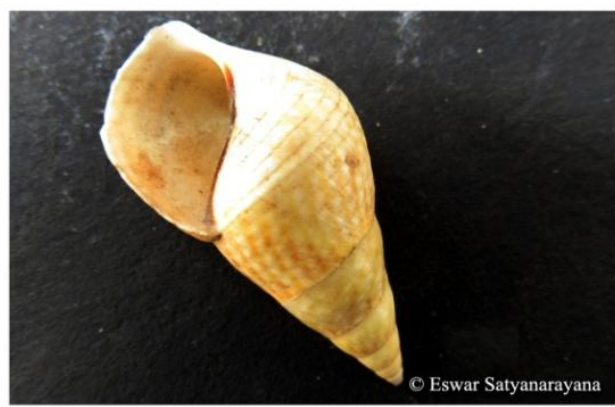

Littoraria melanostoma (Gray, 1839)

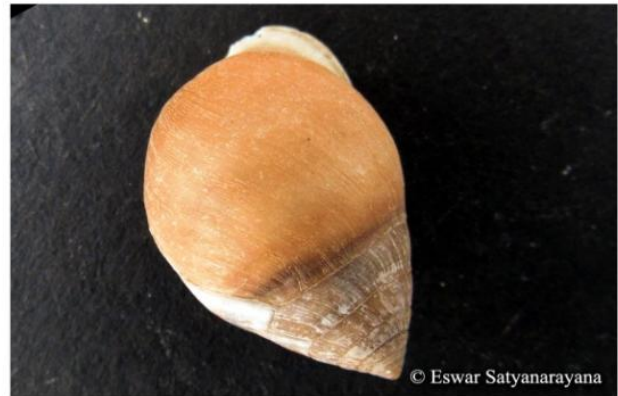

Pythia plicata (Ferussac, 1821)

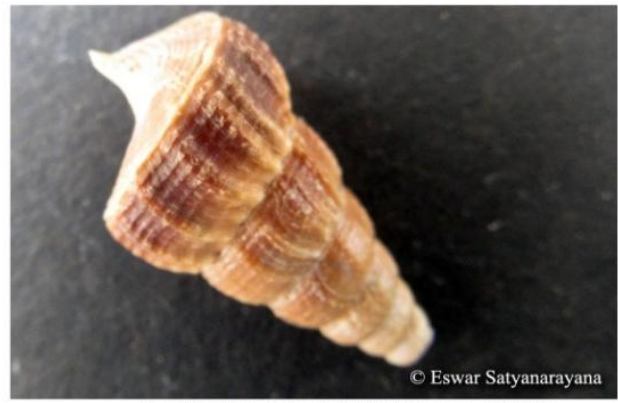

Terebralia palustris (Linnaeus, 1767) 


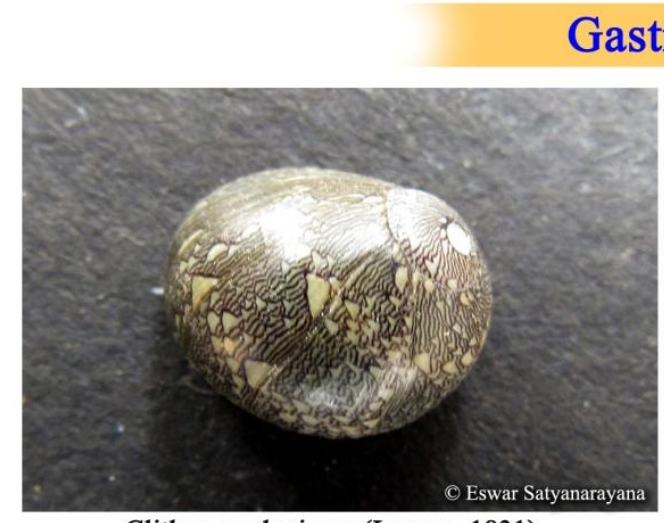

Clithon oualaniense (Lesson, 1831)

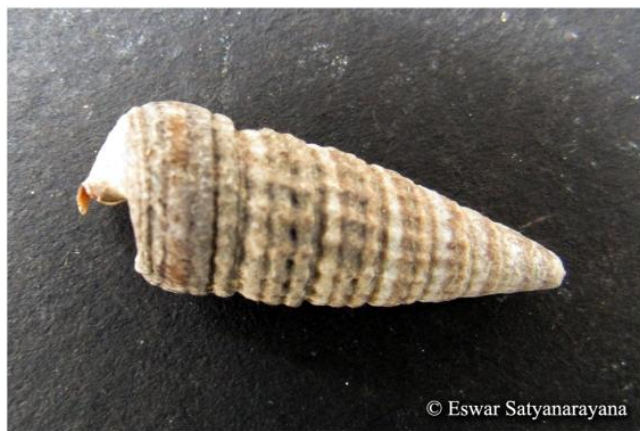

Pirenella cingulata (Gmelin, 1791)

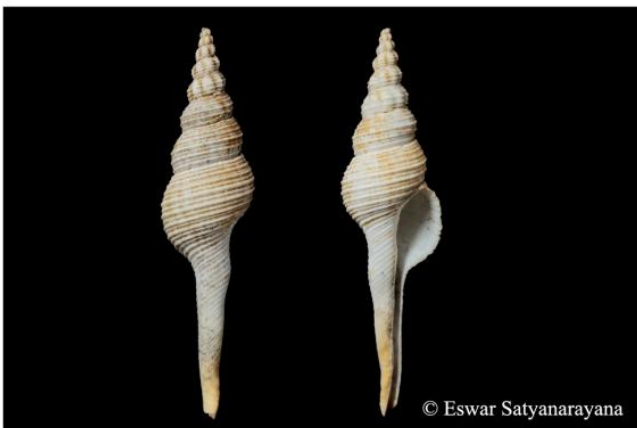

Fusinus colus (Linnaeus ,1758)

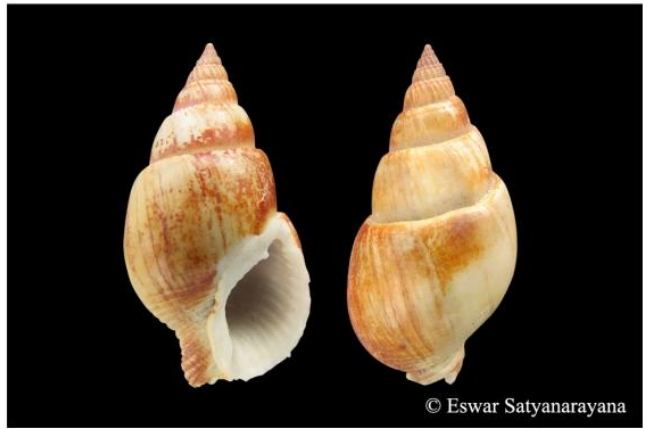

Nassarius dorsatus (Röding, 1798)

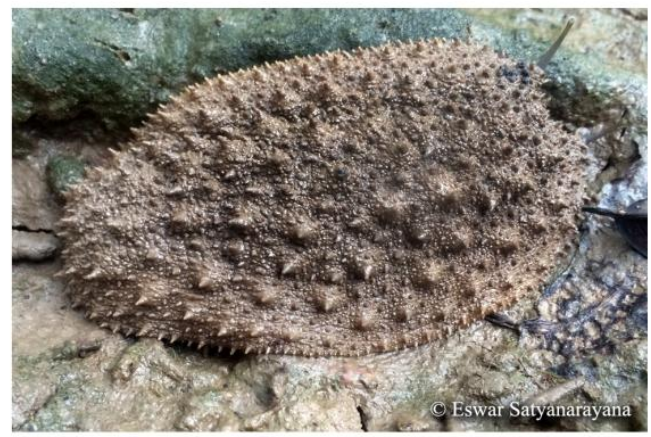

Onchidium Sp.

Species richness and number of individuals were determined and calculated the species diversity by ShannonWiener Index, Table -2. The results shows that the species diversity at Creek A is 1.718 and Creek B is 1.870, the species richness was same for the two creeks and the estuary region. Telescopium telescopium and Cerithidea obtuse are found to be in abundant all over the mangrove areas. During the survey at the time of high tide Cerithidea obtuse tends to avoid the water by crawling on to the trees to a height of $30 \mathrm{~cm}$ to $50 \mathrm{~cm}$. These findings were done during the subsequent surveys for the small carnivores monitoring in the Coringa Wildlife Sanctuary. 
Molluscan fauna (Bivalves) recorded during the study in the Mangrove areas and estuarine regions in East Godavari estuarine ecosystem

\section{Bivalves}

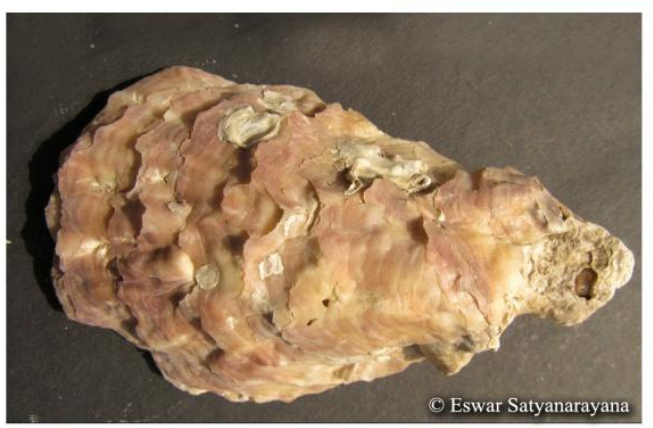

Crassostrea bilineata (Roding, 1798)

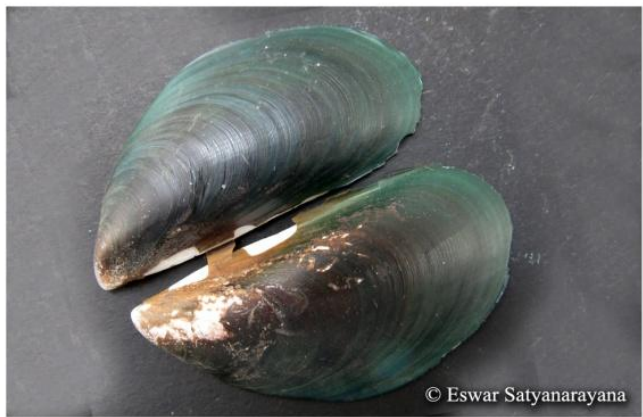

Perna viridis (Linnaeus, 1758)

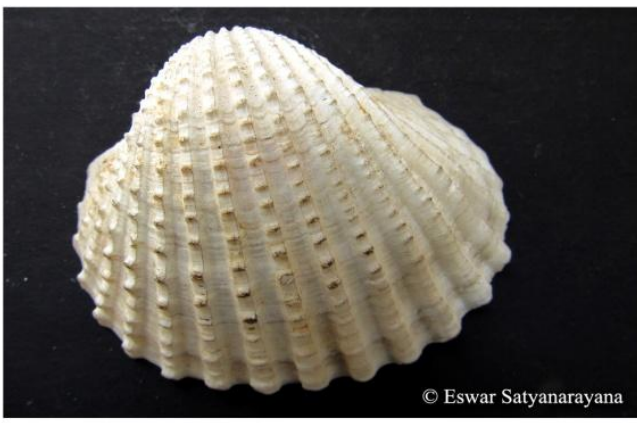

Tegillarca granosa (Linnaeus,1758)

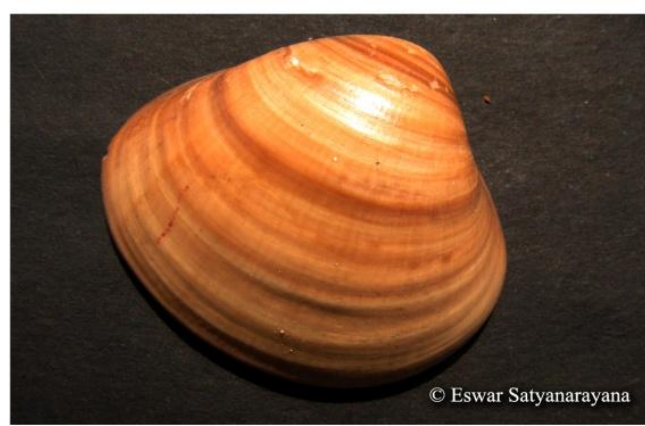

Meretrix meretrix (Linnaeus, 1758)

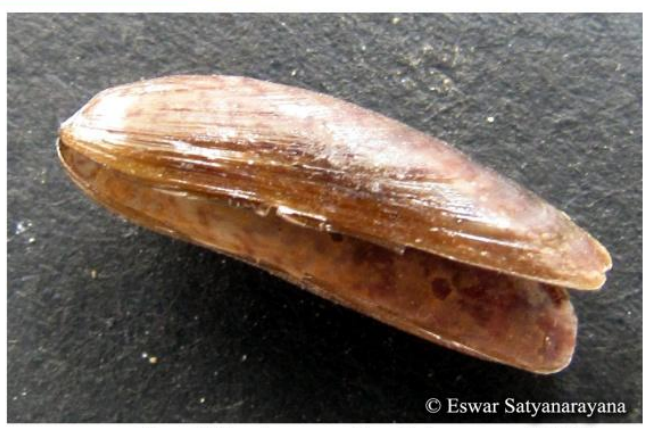

Brachidontes exustus (Linnaeus, 1758)

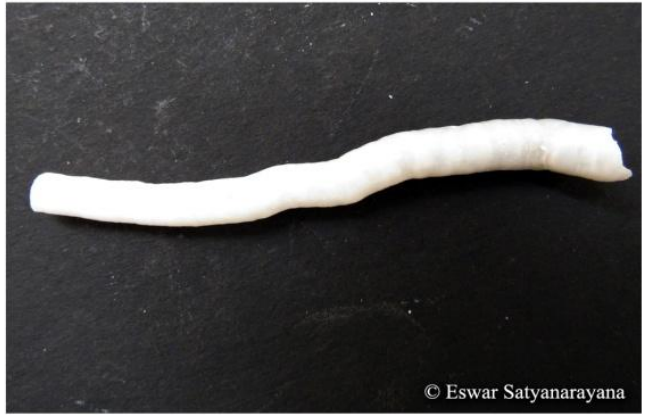

Teredo navalis (Linnaeus, 1758)

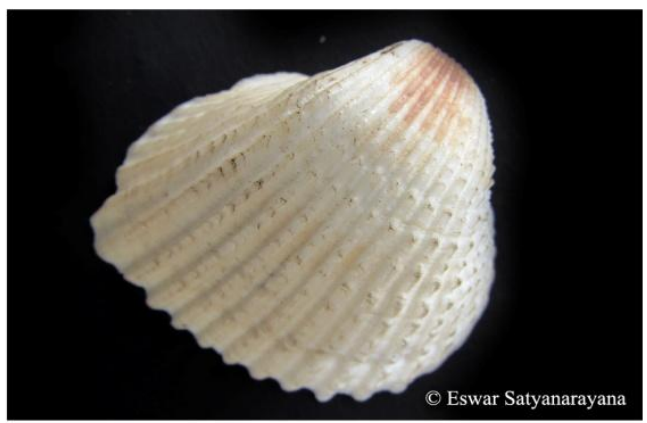

Tegillarca rhombea (Born, 1778)

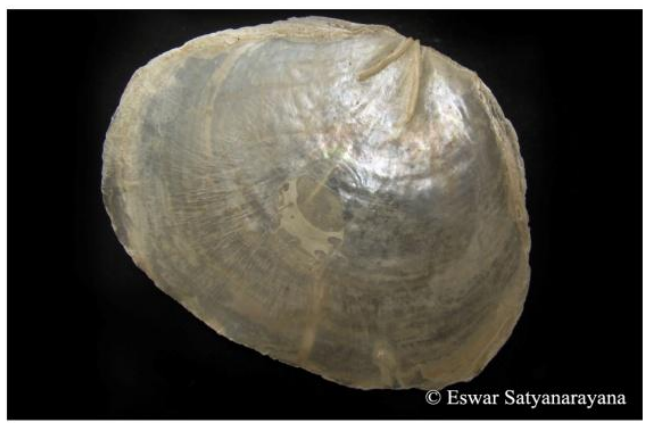

Placuna placenta (Linnaeus,1758) 


\begin{tabular}{|l|c|c|c|c|c|c|c|c|}
\hline \multicolumn{1}{|c|}{ Species } & \multicolumn{2}{|c|}{ Creek A } & \multicolumn{2}{c|}{ Creek B } & \multicolumn{2}{c|}{ Estuary A } & \multicolumn{2}{c|}{ Estuary B } \\
\hline & $\begin{array}{c}\text { Abund } \\
\text { ance }\end{array}$ & $\begin{array}{c}\text { Relative } \\
\text { abundance }\end{array}$ & $\begin{array}{c}\text { Abund } \\
\text { ance }\end{array}$ & $\begin{array}{c}\text { Relati } \\
\text { ve } \\
\text { abund } \\
\text { ance }\end{array}$ & $\begin{array}{c}\text { Abund } \\
\text { ance }\end{array}$ & $\begin{array}{c}\text { Relati } \\
\text { ve } \\
\text { abund } \\
\text { ance }\end{array}$ & $\begin{array}{c}\text { Abund } \\
\text { ance }\end{array}$ & $\begin{array}{c}\text { Relati } \\
\text { ve } \\
\text { abund } \\
\text { ance }\end{array}$ \\
\hline Assiminea brevicula & 24 & 0.088 & 12 & 0.056 & 18 & 0.085 & 42 & 0.197 \\
\hline Fusinus colus & 0 & 0.000 & 0 & 0.000 & 0 & 0.000 & 0 & 0.000 \\
\hline Nassarius dorsatus & 0 & 0.000 & 0 & 0.000 & 0 & 0.000 & 0 & 0.000 \\
\hline Pirenella cingulata & 0 & 0.000 & 0 & 0.000 & 0 & 0.000 & 0 & 0.000 \\
\hline Neripteron violaceum & 30 & 0.109 & 21 & 0.099 & 18 & 0.085 & 25 & 0.117 \\
\hline Pythia plicata & 19 & 0.069 & 18 & 0.085 & 6 & 0.028 & 12 & 0.056 \\
\hline Telescopium telescopium & 68 & 0.248 & 42 & 0.197 & 30 & 0.141 & 20 & 0.094 \\
\hline Terebralia palustris & 12 & 0.044 & 8 & 0.038 & 1 & 0.005 & 3 & 0.014 \\
\hline Clithon oualaniense & 0 & 0.000 & 0 & 0.000 & 0 & 0.000 & 0 & 0.000 \\
\hline Murex trapa & 0 & 0.000 & 0 & 0.000 & 0 & 0.000 & 0 & 0.000 \\
\hline Littoraria melanostoma & 2 & 0.007 & 25 & 0.117 & 0 & 0.000 & 0 & 0.000 \\
\hline Cerithidea obtusa & 54 & 0.197 & 22 & 0.103 & 0 & 0.000 & 0 & 0.000 \\
\hline Cassidula nucleus & 47 & 0.172 & 38 & 0.178 & 39 & 0.183 & 8 & 0.038 \\
\hline Onchidium Sp. & 18 & 0.066 & 27 & 0.127 & 0 & 0.000 & 0 & 0.000 \\
\hline Species Richness (S): & $\mathbf{9}$ & & $\mathbf{9}$ & & $\mathbf{6}$ & & $\mathbf{6}$ & \\
\hline $\begin{array}{l}\text { Number of Individuals } \\
\text { (N): }\end{array}$ & $\mathbf{2 7 4}$ & & $\mathbf{2 1 3}$ & & $\mathbf{1 1 2}$ & & $\mathbf{1 1 0}$ & \\
\hline $\begin{array}{l}\text { Shannon-Wiener Index of } \\
\text { Diversity (H'): }\end{array}$ & $\mathbf{1 . 7 1 8}$ & & $\mathbf{1 . 8 7 0}$ & & $\mathbf{0 . 9 2 1}$ & & $\mathbf{0 . 8 8 8}$ & \\
\hline $\begin{array}{l}\text { Species Evenness } \\
\text { (H'/ln(S)): }\end{array}$ & $\mathbf{0 . 7 8 2}$ & & $\mathbf{0 . 8 5 1}$ & & $\mathbf{0 . 5 1 4}$ & & $\mathbf{0 . 4 9 5}$ & \\
\hline
\end{tabular}

\section{Recommendations:-}

It was evident from the observations that unsustainable harvesting of the shells may cause decline in the populations of some molluscan species in this region. Hence, awareness programmes should be conducted on the sustainable methods of harvest of the shells to the shell collectors in this region.

\section{Acknowledgements:-}

We are grateful to the Government of India, United Nations Development Programme, Global Environment Facility and Government of Andhra Pradesh (GoI-UNDP-GEF-GoAP), EGREE Foundation for their financial support. We wish to acknowledge Dr. K. Thulsi Rao, State Project Coordinator, (GoI-UNDP-GEF-GoAP), EGREE Foundation. We are very much thankful to Mrs. Nirmala Grace, Research Scholar, for her help during the analysis. We wish to acknowledge Mr. B. Naga Prasad for his help in editing and alignment of photos. We also like to acknowledge Mr. D. Mahesh Babu and Mr. P. Ganesh, Field Assistants for their help during the field data collection.

\section{References:-}

1. Al-Sayed, H., Naser H. and Al-Wedaei K. (2008). Observations on macrobenthic invertebrates and wader bird assemblages in a protected marine mudflat in Bahrain. Aquatic Ecosystem Health \& Management, 11(4): 450-456.

2. Barker, G. (2001). The biology of terrestrial molluscs: CABI publishing, Wallingford, UK, 404 p.

3. Boominathan, M., Ravikumar,G, Subash Chandran. M. D and Ramachandra T.V. (2012). Mangrove Associated Molluscs of India. National Conference on Conservation and Management of Wetland Ecosystems, School of Environmental Sciences, Mahatma Gandhi University, Kottayam, Kerala,11Pp.

4. Coull BC, Greenwood JG, Fielder DR, Coull BA (1995). Subtropical Australian juvenile fish eat meio fauna : experiments with winter whiting Sillago maculate and observations on other species. Marine Ecology Progress Series, 125, 13-19.

5. Dewiyanti Irma and Karina Sofuatuddin (2012). Diversity of Gastropods and Bivalves in mangrove ecosystem rehabilitation areas in Aceh Besar and Banda Aceh districts, Indonesia. Aquaculture, Aquarium, Conservation \& Legislation International Journal of the Bioflux Society. 
6. Feldkamp, S. (2002). Modern Biology. Austin: Holt, Rinehart and Winston. ISBN 0030565413. Retrieved 12 April, 2010, from www.textaddons.com

7. Fratini, S., Vannini, M. and Cannicci, S. (2008). Feeding preferences and food searching strategies mediated by air-and water-borne cues in the mud whelk Terebralia palustris (Potamididae: Gastropoda). Journal of Experimental Marine Biology and Ecology, $\quad 362(1)$ : 26-31.

8. Gustavson, K., Kroeker, Z., Walmsley, J. And Juma, S. (2009). A process framework for coastal zone management in Tanzania. Ocean \& Coastal Management, 52(2): 78-88.

9. Jiang JX, Li RG (1995). An ecological study on the mollusca in mangrove areas in the estuary of the Jiulong River. Hydrobiologia, 295, 213-220.

10. Kober, K. (2004). Foraging ecology and habitat use of wading birds and shorebirds in the mangrove ecosystem of the Caeté Bay, Northeast Pará, Brazil. 178p.

11. Lee, H.Y. and Shih, S.S. (2004). Impacts of vegetation changes on the hydraulic and sediment transport characteristics in Guandu mangrove wetland. Ecological Engineering, 23(2): 85-94.

12. Lewis Iii, R.R. (2005). Ecological engineering for successful management and restoration of mangrove forests. Ecological Engineering, 24(4): 403-418.

13. Mardiastuti, A. (2001). Ecology of Avian community of Pulau Rambut: population, nest site distribution and foraging sites. $53 \mathrm{p}$.

14. Milward NE (1982). Mangrove dependent biota. In mangrove ecosystem Australia. (ed. B. Clough). Canberra: Australian National University, 121- 39.

15. Miththapala, S. (2008). Mangroves. Coastal Ecosystems Series: by: Ecosystems and Livelihoods Groups Asia, IUCN. 28 p.

16. Mitsch, W. (2005). Wetland creation, restoration, and conservation: a wetland invitational at the Olentangy River wetland research park. Ecological Engineering, 24(4): 243-251.

17. Narasimham, K. A. 1973. On the moluscan fisheries of the Kakinada Bay. Indian J.Fish., 20: 209-214.

18. Radhakrishna,Y .and P.N .Ganapati.(1967). Fauna of the Kakinada Bay. Bull. Nat. Inst. Soi. India. 38:689699.

19. Redfield J (1982). Trophic relationships in mangrove communities. In mangrove ecosystem in Australia. (ed. B. Clough) Canberra: Australian National University, 259-62.

20. Shanmugam A. And Vairamani S. (2005). Molluscs in Mangroves: A Case study, Centre of Advanced Study in Marine Biology, Annamalai University. P. 371.

21. Smith, A. and Nol, E. (2000). Winter foraging behavior and prey selection of the Semipalmated Plover in coastal Venezuela. The Wilson Bulletin, 112(4): 467-472.

22. Strong, E., Gargominy, O., Ponder, W. And Bouchet, P. (2008). Global diversity of gastropods (Gastropoda; Mollusca) in freshwater. Hydrobiologia, 595(1): 149-166.

23. Varnell, L., Evans, D. and Havens, K. (2003). A geomorphological model of intertidal cove marshes with application to wetlands management. Ecological Engineering, 19(5): 339-347.

24. Vermeij, G. (1973). Molluscs in mangrove swamps: physiognomy, diversity, and regional differences. Systematic Biology, 22(4): 609.

25. Walters, B.B., Rönnbäck, P., Kovacs, J.M., Crona, B., Hussain, S.A. and Badola, R. $\quad$ (2008). Ethnobiology, socio-economics and management of mangrove forests: A review. Aquatic Botany, 89(2): 220-236.

26. Wells FE (1983). An analysis of marine invertebrates distribution in a mangrove swamp in northwestern Australia. Bulletin of Marine Science, 33, 736-44.

27. Wells FE (1990). Distribution of marine invertebrates in Hong Kong Mangroves, with emphasis on Molluscs. Proceedings of the second international Marine Biological Workshop: The Marine Flora and Fauna of Hong Kong and Southern China, Hong Kong, 1986. (ed. B. Morton) Hong Kong. Hong Kong University Press: 783-793.

28. Zhang, C.G., Leung, I.K.K., Wong, Y.S. and TAM, N.F. Y. (2007). Germination, growth and physiological responses of mangrove plant (Bruguiera gymnorrhiza) to lubricating oil pollution. Environmental and Experimental Botany, 60: 127-136.

29. Zhou, Y., Zhao, B., Peng, Y. and Chen, G. (2010). Influence of mangrove reforestation on heavy metal accumulation and speciation in intertidal sediments. Marine Pollution ～Bulletin, 60(8): 1319-1324. 